Interdisciplinary Studies of Complex Systems

No. 15 (2019) 21-33

(c) Н. Таценко

https://doi.org/10.31392/iscs.2019.15.021

\title{
НОВИЙ МЕТОД ДОСЛІДЖЕННЯ У СУЧАСНИХ НАУКОВИХ ЛІНГВІСТИЧНИХ РОЗВІДКАХ
}

\author{
Наталія Таценко
}

\begin{abstract}
Анотація. Центральною темою статті є обгрунтування фрактального підходу до аналізу дискурсу в сучасних лінгвістичних дослідженнях. Стверджується, що фрактальний метод аналізу в дискурсі - це визначення самоподібності його складників задля більш глибокого наукового пізнання та можливості прогнозування появи тих чи інших елементів дискурсивної системи. За такого підходу дискурс визначається як багатовимірна фрактально організована когнітивно-комунікативно-мовна система, здатна до самоорганізації та самоподібного розвитку, детермінована динамікою конструювання смислів, ідей і переконань, взаємодією комунікантів у певних соціально-культурних контекстах та матеріалізована у вигляді вербальних і невербальних знаків. Відтак, соціальнопрагматичний аспект дискурсу передбачає багаторазове фрактальне тиражування його графічних утілень за збереження ідентичності смислу задля посилення впливу на адресата. Показовим $є$ те, що фрактальний потенціал $є$ імпульсом до тиражування когнітивних структур у дискурсі. Фрактальний аналіз значно спрощує процедуру наукового пізнання в лінгвістиці, дозволяе чітко окреслити матеріальність та інтерпретованість дискурсивної системи.
\end{abstract}

Ключові слова: дискурс, рекурсія, самоорганізація, самоподібність, система, фрактал

\section{A NEW RESEARCH METHOD IN MODERN SCIENTIFIC LINGUISTIC STUDIES}

\author{
Nataliia Tatsenko
}

\begin{abstract}
The focal topic of this paper is the discussion of a fractal perspective on the analysis of discourse in modern linguistic research. It is stated that the fractal method of analysis in discourse is the identification of self-similarity of its components for the sake of deeper scientific knowledge and the ability to predict the appearance of certain elements of the discursive system. Within this approach, discourse is defined as a multidimensional, fractally organized cognitive-communicative-linguistic system capable of self-organization and selfdevelopment, determined by the dynamics of the formation of meaning, ideas, and beliefs, by the interaction of communicants in certain socio-cultural contexts, and materialized in the form of verbal and nonverbal signs. Therefore, the social-pragmatic aspect of discourse involves multiple fractal replication of its graphic embodiments with preserving the identity of its meaning in order to increase the impact on the addressee. It is significant that the fractal potential is an impulse to replicate cognitive structures in discourse. Fractal analysis greatly simplifies the procedure of obtaining scientific knowledge in linguistics, allows you to clearly outline the materiality and interpretation nature of the discursive system.
\end{abstract}

Keywords: discourse, fractal, recursion, self-organization, self-similarity, system

\footnotetext{
${ }^{1}$ Сумський державний університет, Суми, Україна. n.tatsenko@gf.sumdu.edu.ua, https://orcid.org/0000-0003-2604-2340.
} 


\section{1. Вступ}

Одним із найперспективніших підходів, що формують універсальну наукову парадигму, є міждисциплінарність із їі адаптивністю, відкритістю до поповнення новими методами, толерантністю до нових гіпотез, спадкоємністю та філософським полілогом. За допомогою об'єднання знання, що генерується різними науковими сферами, долаються комунікативні бар'єри й відбувається становлення нової інтегративної картини світу - трансдисциплінарної парадигми складності (complexity paradigm), яку ще називають теорією складності (complexity theory) або теорією динамічних систем (dynamical systems theory) (Garcia 1999, 281). У вітчизняній лінгвістиці дослідження мови й дискурсу як динамічних систем отримали новий поштовх завдяки методам лінгвосинергетики (Єнікєєва 2011; Домброван 2014; Пихтовникова 2015; Таценко 2018). Метамова останньої сприяє розв'язанню багатьох наукових лінгвістичних проблем, а одним із найуживаніших термінів лінгвосинергетики $\epsilon$ «рактальність».

Залучаючи фрактальну геометрію до аналізу системи словотвору, представниця української школи лінгвосинергетики С. М. Єнікєєва (2011, 1416) подає її як величезний «макрофрактал», структурно подібний до «мікрофракталів» - комплексних мікросистем словотвору. У такому разі мікрофрактали словотвірних моделей, рядів, гнізд, алігатур постають порівняно автономними стереоскопічними об'єктами, ізоморфними за принципами будови кожного типу словотвірних мікросистем. Кожний елемент такої мікросистеми має потенційну здатність породжувати нові одиниці, у такий спосіб добудовуючи й розвиваючи їі.

T. I. Домброван (2014) використовує фрактальність задля опису моделі розвитку англійської мови, що охоплює декілька рівнів: складнопідрядні речення, словотвір, побудову словосполучень. Дослідниця вважає, що в основу цього явища покладено єдину суб'єктно-предикативну структуру. Із фрактального погляду також пояснює «фазовий перехід» у мовній системі Л. С. Піхтовнікова $(2015,119-122)$, розглядаючи його на прикладах «нанизування» підрядних речень (у кожному підрядному реченні містяться повтори та/або вказівні й визначальні займенники, що змушує вважати конструкцію самоподібною); використання дієслівних часів (якщо розміщувати всі форми вираження часу одного дієслова за зростанням складності, то така умоглядна шкала $є$ фракталом); конкуренції фракталів рими й метричних схем у віршованих текстах. 3'ясовано, що фрактальність характерна і для концепту як одиниці концептуальної картини світу. Кожний з елементів концепту (когнітивний, афективний, перцептивний, комунікативний) тягне за собою інші, розгортаючись у дискурсі у вигляді фрактала - рекурсії ідеї, смислу, сюжету та форм їхнього викладення (Таценко 2018).

Оригінальним підходом до опису фрактальності мовної системи постає концепція взаємної триєдності матерії, енергії й інформації. Ці складники репрезентують новий погляд на будову мовної системи: фонему як елемент фонетичного рівня мови визначено триєдністю «матерія - звукова, графічна чи інша матеріальна форма, енергія - меризми, інформація - код, який зчитується сенсорним аналізатором». Згідно з цим підходом у мовній системі матерією є її елементи (фонема, морфема тощо), 
енергією - функції цих елементів (перцептивна, делімітативна, сигніфікативна, номінативна, комунікативна), а інформацією - одиниці сприйняття (Симонов 2013, 11-42).

Ю. Є. Кійко (2017) змоделював інваріантно-варіантну структуру медіатекстів, яка грунтується на універсальному принципі фрактальної будови навколишнього світу та його об’єктів. Розглядаючи текст як матеріальне втілення дискурсу, науковець зауважує, що текст є певним плетінням, яке складається з частинок і теоретично $є$ нескінченним, подібно до історії «1001 ночі» (Кійко 2017, 91-92). Під частинами маємо розуміти зростання фонеми, морфеми, слова, синтагми, речення, диктеми тощо. Фрактальність виявляється в тексті на рівні змісту й на рівні його викладення. У першому випадку йдеться про те, що повторюється ідея, сюжет, а в другому - форма викладу матеріалу. Текст є продуктом, статичним об'єктом, у якому зафіксована людська ментальна діяльність; подібно до закам'янілого дерева, він створюється на грунті рекурентності і шкалювання в обох напрямах: збільшення або зменшення обсягу. Тобто, будь-який текст перебуває на певному етапі тематичного розгортання від слова-тексту через речення-текст до дискурсу. Окремо взятий текст розглядається як фрактал тематичного дискурсу, який можливо образно подати безмежним інформаційним простором.

Не зважаючи на активне використання фрактальної розмірності у вивченні різних аспектів дискурсу, не визначеною залишається сутність фрактального аналізу як методу дослідження. У чому він полягає й навіщо залучати його до дискурсивних студій? Крім того, для забезпечення цілісності й гармонії людської комунікації через призму фрактальності, необхідно в дещо новому руслі осмислити поняття «дискурс». Це і є метою статті. У дослідженні використано такі методи: теоретичне узагальнення, аналіз та синтез, абстрагування для побудови основної гіпотези статті; метод екстраполяції базових принципів фрактальної теорії на методологію дискурсивного аналізу для відтворення динаміки дискурсу та вибудовування фрактального методу дискурсивних студій; тезаурусний аналіз для розкриття сутності фрактала та дискурсу в різних дефініціях; інтерпретаційнотекстовий аналіз для з'ясування особливостей фрактальної рекурсії в дискурсі.

\section{2. Результати та дискусії}

Фрактальний вимір універсуму започаткований дослідженнями відомого математика Б. Мандельбро (Mandelbrot 1982, 18-31), який увів термін «фрактал» для позначення множини, розмірність якої не збігається зі звичайною. Цей термін походить від латинського прикметника fractus і в перекладі означає «нерівний, негладкий, той, що складається з фрагментів», а відповідне латинське дієслово frangere означає «розбивати, тобто створювати неправильні фрагменти» (Дворецкий 2000, 335). Б. Мандельбро (Mandelbrot 1982) започаткував геометрію природи, яка, на відміну від евклідової геометрії (геометрії штучно створених людиною фігур), створюється на грунті нескінченного процесу «ітерації» (повторення), подрібнюючись на менші самоподібні частини. Так, ліс загалом має форму окремого 
дерева, кожний найменший фрагмент берегової лінії повторює її загальний контур, а хмара за структурою дорівнює своїм окремим хмаринкам. Це відкриття уможливило вимірювання об'єктів, які раніше вважалися невимірними.

З упевненістю підтримую думку науковців про те, що ще давні філософи застосовували принцип аналогії всього сущого або редукціонізм, який перегукується із фрактальним підходом. Зазначається, що фрактальність $\epsilon$ підгрунтям еволюції різних систем, оскільки процес фізичного, біологічного чи соціального розвитку $є$ безмежною сукупністю тимчасових, взаємозалежних самоподібних проміжних станів/процесів. Тому все, що виявляється у великому (макрокосмосі), міститься в малому (мікрокосмосі) і навпаки. Зазначена ідея відображена у відомій фразі Сократа «Пізнай себе, і ти пізнаєш світ» (Кійко 2017, 88). Фрактальна система виникає із мікрофрактала (алгоритму розвитку, що несе спадкову інформацію про систему) - структури, що містить щільно згорнуту інформацію та величезну потенційну енергію, яка дає імпульс системі. Згорнута інформація містить фрактальну еволюцію системи (усі її можливі траєкторії та шляхи розвитку), а енергія дозволяє перейти з потенційного стану в наявний, тобто, $є$ запорукою виникнення.

Інваріантність (фундаментальна властивість геометричної регулярності) характеризує багато структур матеріального світу. Вона є особливою формою симетрії, фрагменти цілісності якої структурно подібні. Фрактальна розмірність дає надзвичайно компактний спосіб опису об'єктів і процесів, постаючи перехідним квазістійким станом системи, що характеризується хаотичністю й нестабільністю, яка поступово еволюціонує до стійкого, впорядкованого цілого. Таке мережеве утворення наявне серед подібних собі об'єктів і нескінченно повторює себе на різних рівнях. Фрактальна система зростає відповідно до заданого алгоритмом розвитку, поділяється і знову зростає. У такий спосіб утворюється сукупність систем, підсистем і надсистем, подібних одна одній (Таценко 2017). Наведена концепція сприяє розумінню процесів світового розвитку, створюючи цілісну картину руху матерії від простих форм організації до складних.

Підгрунтя дискурсу як середовища конструювання смислів складають ідеї фрактальної геометрії. Саморегульованість дискурсу базується на тому факті, що абсолютні значення порядку й хаосу є згубними для його життєздатності. 3 одного боку, комунікація можлива лише в разі, коли в розпорядженні учасників $є$ такі стійкі структури, як фонетика, лексика i граматика. Їхня стабільність спричиняє спільність мовного досвіду й гарантує інформативну доступність висловлювання для адресата, оскільки в умовах абсолютного хаосу комуніканти не досягнуть розуміння. 3 іншого боку, потребам інтеракції не відповідає й повний порядок, оскільки статично й жорстко організована система мовних засобів призведе до повної передбачуваності й безглуздості комунікації. Звідси висновок: дискурс повинен поєднувати риси новизни, невизначеності (виявів хаотичної основи) та стійкості й передбачуваності (виявів порядку). Для дослідження цих виявів і використовується принцип фрактальності, оскільки загальною властивістю фрактальної системи $є$ факт структурування нею хаосу, невизначеності. 
Фрактальні простори дискурсу самоорганізуються за принципом живого наростаючого знання й самі вилучають із себе когнітивний аспект, що є основним для їхнього формування (Плотникова 2011, 133). Підкорення хаосу пов'язано з тим, що кожний наявний фрактал створює поруч із собою «віртуальний фрактал» (який актуалізується слідом за ним), оскільки несе в собі алгоритм свого подальшого розвитку. До прикладу, виникнення геометричної фрактальності створило нові знання в науці загалом, ці знання матеріалізувалися в різних науках, і наразі дослідники аналізують історичні, економічні, лінгвістичні фрактали, які за своєю структурою подібні геометричним. У цьому аспекті фрактальна система $є$ надзвичайно стійкою, адже внутрішні флуктуації не здатні ї̈ зруйнувати, це можливо лише за масштабного глобального зовнішнього впливу.

Зазначені твердження змушують по-новому розглянути поняття дискурсу, переосмислити його визначення. Т. ван Дейк $(1989,58)$, засновник сучасної теорії дискурсу, розглядає останній як комунікативну подію, складну єдність мовної форми, значення та дії, відтворену комунікантами, у якій задіяна не лише мова в їі фактичному використанні, але й ті ментальні процеси, що постійно супроводжують комунікацію, а також спосіб актуалізації тексту в певних ментальних і прагматичних умовах. I. С. Шевченко (2017, 115-116) визначає дискурс як багатоаспектну когнітивно-комунікативно-мовну систему-гештальт, що визначається сукупністю трьох аспектів: формуванням ідей і переконань (когнітивний аспект) взаємодією комунікантів у певних соціально-культурних контекстах/ситуаціях (соціально-прагматичний аспект) та використанням знаків, вербальних і паравербальних (мовний аспект).

Загалом за своєю суттю дискурс - це когнітивне явище, оскільки взаємодія комунікантів $є$ передачею знань, а використання знаків - це матеріалізація когнітивної діяльності людини під час створення нових знань. Використання мови $є$ переходом від одного структурного стану когніції до іншого, тобто поведінкою когнітивної системи індивіда. Механізми функціонування дискурсу, його розвитку як когнітивного явища $є$ фрактальними. Отже, дискурс необхідно розглядати як багатовимірну фрактально організовану когнітивно-комунікативно-мовну систему, здатну до самоорганізації та самоподібного розвитку, що визначається динамікою конструювання смислів, ідей і переконань, взаємодією комунікантів у певних соціально-культурних контекстах та матеріалізацією когнітивної діяльності у вигляді вербальних і невербальних знаків.

На мою думку, підтвердження цієї гіпотези слід почати з генеративної дедуктивної теорії Н. Хомського (Chomsky 1993), спрямованої на побудову загальної теоретичної моделі мовленнєвої діяльності людини. Відомий лінгвіст уважає, що в інформаційній системі людської когніції $є$ програма або модуль, основним завданням якого є породження синтаксичних структур з обмеженої кількості фразових блоків. Ця процедура відбувається за певними алгоритмами, які за своєю суттю є рекурсивними правилами, що забезпечують можливість «укладання» блокових структур одна в одну задля продовження синтаксичного ряду. Синтаксична підсистема мовного модуля є вродженою універсальною «граматикою форм», вбудованою в апарат 
людського мислення. Метою генеративної теорії є аналіз ментального механізму, що використовує скінченне число початкових елементів для генерації нескінченного числа граматично правильних речень. На різних етапах розвитку певні постулати теорії Н. Хомського змінювалися, утім незмінною залишилося поняття рекурсивного породження синтаксичних структур.

Рекурсія є способом організації складної системи, за якого виокремлюється певний набір базових підсистем; система здатна в процесі свого функціонування створювати необмежену кількість копій базових систем, здійснювати взаємодію між ними, i, якщо необхідно, знищувати їх; функціонування складної системи полягає у функціонуванні активних копій базових підсистем; під час запиту копій допустима ї̈ зміна, що визначається ситуацією в момент запиту. 3 одного боку, рекурсивна система завдяки створенню власних копій одержує можливість необмеженого зростання й ускладнення, з іншого боку, ця складність має організований вид, який визначається локальними правилами функціонування (Личутин 2006). Слід наголосити, що рекурсивність та алгоритмізація є не що інше, як характеристики фрактальної розмірності.

Представники лінгвістичного мейнстріму, що конкурує з генеративізмом - сучасної когнітивної лінгвістики - досліджують ментальне підгрунтя семіотичних феноменів мови та мовлення. Задля аналізу значень вербальних одиниць використовується концептуальний аналіз, суть якого полягає в упорядкуванні вербалізованої інформації за допомогою узагальнених схемних структур. Зокрема, автор методики Семантики лінгвальних мереж (СЛМ) С.А. Жаботинська (2013; 2018) використовує набір узагальнених понятійних структур, відстежених у значеннях та формах мовних i мовленнєвих одиниць різних рівнів. Концептуальні мережі, що структурують значення мовних і мовленнєвих знаків, формуються базовими пропозиційними схемами (БПС), які мають найвищий рівень узагальнення та являють собою первинні категорії мислення й типи реляцій між ними. Тип пропозиційної схеми визначається за її належністю до одного 3 п'яти базових фреймів - предметного, акціонального, посесивного, ідентифікаційного та компаративного. Кількість схем обмежена, але завдяки їхній різноманітній комбінаториці, яка залежить від специфіки понятійного простору, що структурується, отримується необмежена кількість різних конфігурацій концептуальних мереж (Жаботинская 2018).

Зазначається, що концептуальна мережева модель перетворюється в матричну модель, якщо зв'язки між інформаційними вузлами мережі залишаються невизначеними, імпліцитними. Залежно від потреб дослідження, концептуальні мережі будуються як одновимірні та багатовимірні (мережі в мережах). Багатовимірна мережа передбачає наявність понятійних просторів, що розгортаються «вглиб». Концептосфера (увесь структурований семантичний простір) $є$ мережею доменів (понятійних вузлів концептосфери); кожен домен є мережею парцел (понятійних вузлів домена); парцела містить конкретні предметні концепти, кожен із яких $є$ інформаційним вузлом, модельованим мережею ознак. На всіх концептуальних рівнях побудова мережі здійснюється за допомогою БПС, котрі демонструють якості понятійних фракталів - схожих форм, відтворюваних у різних масштабах 
(Жаботинская 2018, 113-114). Для Семантики лінгвальних мереж ідея рекурсивності понятійних та мовних структур є основоположною (там само, 132). Вона спирається на положення когнітивної граматики Р. Ленекера (2008, 44-45) про ієрархію концептуальних доменів та можливість їхнього «вкладення» один в одного.

Крім того, за С.А. Жаботинською (2018, 116-118), під час створення вербального знака має місце послідовне ономасіологічне картування - фрагментарна репрезентація інформації, що розгортається в напрямку «зовнішній світ $\rightarrow$ інформація у свідомості (значення) $\rightarrow$ внутрішня форма знака $\rightarrow$ зовнішня форма знака $1 \rightarrow$ зовнішня форма знака 2 . На моє глибоке переконання, ця схема є яскравим прикладом фрактального згортання та розгортання інформації. Свідомість картує, згортає зовнішню інформацію, яка стає значенням для потенційного знака (схема «зовнішній світ $\rightarrow$ інформація у свідомості»). Наприклад: $X$ is a machine that stores programs and information in electronic form and can be used for a variety of processes, for example writing, calculating, and communicating on the Internet. У складі значення обирається певний фрагмент, що виконує роль мотиватора, забезпечуючи доступ до цього значення, тобто, є ще раз згорнутим значенням. Цей фрагмент $€$ внутрішньою формою знака (схема «інформація у свідомості $\rightarrow$ внутрішня форма знака»). Наприклад: $X$ can be used for communicating on the Internet personal computer. Структура зовнішньої форми знака, його матеріальної оболонки, досить часто об'єктивує ономасіологічну модель внутрішньої форми лише частково, тобто, ще раз згортається (схема «внутрішня форма знака $\rightarrow$ зовнішня форма знака»). Наприклад: personal computer $\rightarrow$ computer. Досить часто більша зовнішня форма знака картується меншою, тобто, ще раз згортається (схема «зовнішня форма знака $1 \rightarrow$ зовнішня форма знака $2 »)$. Наприклад: computer $\rightarrow$ $P C$. Цей процес водночас відбувається й у зворотньому напрямку. Таким чином, упорядкування вербалізованої інформації функціонує за законами фрактальних систем.

Цей факт наводить на думку про те, що в людській свідомості завжди відтворюється зменшена структурна копія або фрактал соціальнокультурного оточення та подій. Матеріально цей фрактал втілюється у формі знаків. Якщо говорити про мовні знаки, то єдність мови та ієрархічна впорядкованість усіх розміщених у ній підструктур забезпечуються телескопійною організацією за принципом вкладеності одних компонентів у інші, що уможливлює їхн порівняно легке згортання в структури різного обсягу (слово, словосполучення, речення, текст). Смисл окремого речення вміщує смисл усього попереднього тексту, узагальнює його або містить у собі схему майбутнього розвитку сюжету, передбачаючи його.

Яскравим прикладом фрактальності $є$ анотація статті в науковому дискурсі, трейлер фільму в кінодискурсі, тези лекції в навчальному дискурсі, скорочений огляд новин у теледискурсі тощо, де відбувається згортання інформації, її подання в стислому вигляді разом із розширеним варіантом. Наведу приклад фрактальності тексту із сайту газети The New York Times (2019) про пожежу в Соборі Паризької Богоматері (Нотр-Дам де Парі): 
(1) Notre-dame will be rebielt, macron says, as fire is extinguished

By Aurelien Breeden, Elian Peltier and Austin Ramzy

April 16, 2019

(2) PARIS - The fire that roared through Notre-Dame has been extinguished, officials said on Tuesday, after President Emmanuel Macron of France vowed to rebuild the cathedral, a beloved symbol of the city for more than eight centuries, and prosecutors began investigating what caused the blaze that badly damaged a world-renowned jewel of Gothic architecture.

(3) Just hours after the cathedral's lacy spire and much of its roof collapsed amid leaping flames and smoke on Monday, Mr. Macron stood outside the stillburning structure and said an international effort to raise funds for reconstruction would begin Tuesday. "We will rebuild Notre-Dame," he said. "Because that is what the French expect."

The billionaire Pinault family of France pledged 100 million euros, or about $\$ 113$ million, to the effort, Agence-France Presse reported, and the family of Bernard Arnault, owners of the luxury goods group LVMH Moët Hennessy Louis Vuitton, plan to contribute €200 million.

The first fire alarm on Monday was triggered at 6:20 p.m., and checks were carried out but no fire was found, the Paris prosecutor, Rémy Heitz, said on Tuesday. A second alarm went off at 6:43 p.m., he said, and fire was discovered in the wooden framework of the attic.

"In the meantime, the cathedral had been evacuated, because a Mass had started shortly before," he said.

Mr. Heitz said that nearly 50 investigators were working to determine the cause of the fire, interviewing workers and other witnesses, but that "it will be a long and complex investigation." So far, the fire appears to have been an accident, he said, adding, "Nothing at this stage suggests a voluntary act."

В огляді новин виокремлено такі складники: (1) заголовок, (2) «лід» (короткий виклад матеріалу (термін журналістики)) та (3) текст повідомлення. Заголовок є початковим фракталом тексту, лід - проміжним, а текст повідомлення - кінцевим. Заголовок $є$ найменшим квантом інформації, де надається основна ідея тексту (повідомляється, що Собор Паризької Богоматері буде відбудований, оскільки пожежу вгамовано). Пропозиція заголовка конкретизується, стисло відтворюючись у ліді (додається інформація про те, $x m o$, що, де та коли). У самому тексті повідомлення пропозиція знову повторюється, набуває тематичного розгортання, вводяться підтеми, тобто, смислова структура циклічно ускладнюється. У такий спосіб початковий, проміжний та кінцевий фрактали $є$ рекурсивними на рівні змісту (повторюється тема) і на рівні його відбиття (повторюється форма викладення інформаціі). Вони розглядаються адресатом як автономні (на кожному із них прийняття інформації за бажанням адресата здатне припинитися в разі відсутності інтересу до неї). Цю точку зору відображено у вигляді піраміди (див. рис. 1):

Слід також проаналізувати структуру сучасної наукової статті. Зазвичай, використовується модель IMRaD (Introduction - Methods - Results and Discussion), що була запропонована видатним французьким мікробіологом і хіміком Луї Пастером у XIX ст. Головною перевагою моделі вва- 


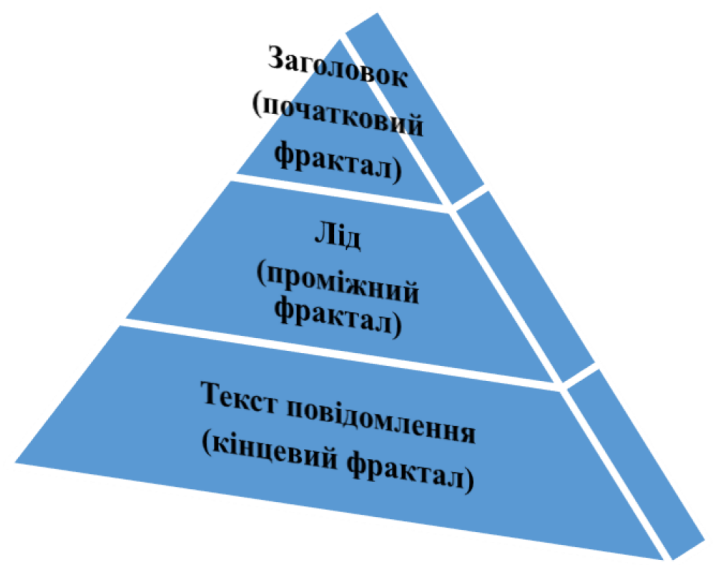

Рис. 1. Приклад організації дискурсивних фракталів

жається їі компактність та лаконічність, що дозволяє видавництвам продуктивно співпрацювати з авторами й рецензентами та ефективно використовувати журнальний простір (див. рис. 2). На моє глибоке переконання, успіхом ця модель завдячує насамперед тому, що інформація в ній послідовно згортається та розгортається. Спочатку - згорнута назва, потім дещо розширена анотація, далі - вступ, що охоплює всю проблему загалом, потім у методах та результатах автори звужують проблему до своєї тематики, вибудовуючи концепцію, а наприкінці знову розширюють, екстраполюють їі на загальний стан розвитку певного напряму науки. Усі частини повинні бути фрактально рекурсивні, інакше стаття не $є$ якісною.

Наступним прикладом є уривок із книги «Гра престолів» ("A Game of Thrones"), у якій один із персонажів (Джон) виражає співчуття до іншого персонажа (Сема), намагаючись відмовити своїх друзів від спроб убити останнього:

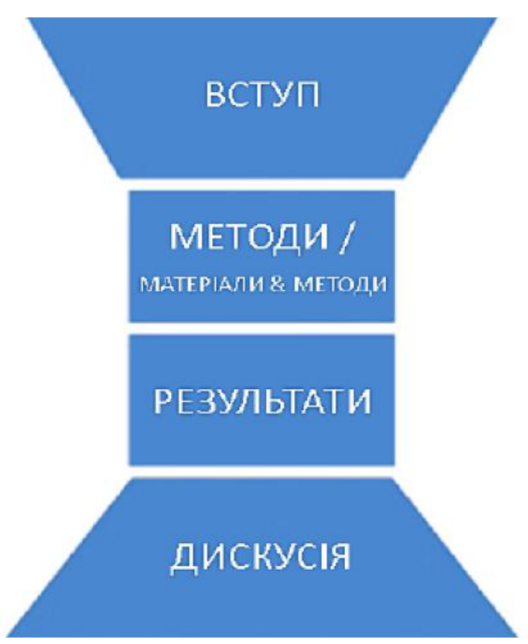

Рис. 2. Модель наукової статті IMRaD 
John glanced warily at Chett, standing beside the door, his boils red and angry. "He could help you," he said quickly. "He can do sums, and he knows how to read and write. I know Chett can't read, and Clydas has weak eyes. Sam read every book in his father's library. He'd be good with the ravens too. Animals seem to like him. Ghost took to him straight off. There's a lot he could do, besides fighting. The Night's Watch needs every man. Why kill one, to no end? Make use of him instead." (Martin 2011, 436).

У цьому прикладі смисл виразу He could help you (він здатний допомогти тобі) повторюється у виразах He can do sums (він здатний рахувати), he knows how to read and write (він уміє читати й писати), Sam read every book in his father's library (Сем прочитав кожну книгу в бібліотеці свого батька), He'd be good with the ravens too (він би зміг упоратися 3 круками), Animals seem to like him (здається, його люблять тварини), Ghost took to him straight off (він зразу сподобався привиду), There's a lot he could do, besides fighting (він міг би багато зробити, крім участі в боях), The Night's Watch needs every man (нічній варті потрібна кожна особа), Why kill one, to no end? (Навіщо даремно вбивати його?) Make use of him instead (Використаємо його натомість). Кожна рекурсивна інтерпретація $\epsilon$ завершеним смислом і залучає нові смисли, однак усі вони пов'язані між собою й виражають домінантний смисл, закладений у першому й останньому виразах: він здатний допомогти, використаємо це. Смислова віднесеність рекурсивних інтерпретацій до того самого референта та їхня тематична неперервність увиразнює прагматичний ефект висловлення. Це наводить на висновок про те, що, якщо ту саму думку з приблизною точністю виразити різними словами й різними синтаксичними конструкціями із залученням імплікатур, тобто використати фрактальну рекурсію смислу, це підвищить вплив на співрозмовника й у такий спосіб сприятиме успішній комунікації.

Дослідження дискурсивних фракталів, співставлення згорнутої та розгорнутої інформації дозволяє аналізувати сукупність елементів дискурсу в межах усіх рівнів. Фрактал виступає активною моделлю, за допомогою якої пояснюється взаємозалежність і взаємодія якісної упорядкованості всіх рівнів дискурсивної системи.

\section{Висновки}

Фрактали складають підгрунтя дискурсу, його ресурс. Нове в дискурci виникає як раптове й непередбачуване, але воно водночас запрограмоване в сукупності шляхів розвитку, що мають фрактальну розмірність. За такого підходу дискурс визначається як багатовимірна фрактально організована когнітивно-комунікативно-мовна система, здатна до самоорганізації та самоподібного розвитку, детермінована динамікою конструювання смислів, ідей і переконань, взаємодією комунікантів у певних соціальнокультурних контекстах та матеріалізована у вигляді вербальних і невербальних знаків.

Кожна нова інтерпретація під час фрактальної рекурсії дає можливість залучати практично необмежену кількість смислових елементів, пов'язаних із домінантним смислом. Водночас властивість самоподібності, забезпечуючи виконання закону єдності в різноманітності, породжує цілісне сприйняття дискурсу. Соціально-прагматичний аспект дискурсу передба- 
чає багаторазове фрактальне тиражування графічних утілень останнього за збереження ідентичності смислу задля посилення впливу на адресата. Фрактальний потенціал $\epsilon$ не чим іншим, як імпульсом до тиражування когнітивних структур.

Фрактальний метод аналізу в дискурсі - це визначення самоподібності його складників задля більш глибокого дослідження та можливості прогнозування появи тих чи інших елементів дискурсивної системи. Показовим $є$ те, що теорія фракталів дозволяє виявити закономірність у хаотичній дискурсивній системі, постаючи одночасно обмежувальним чинником і генерувальним інструментом. Така стратегія значно спрощує процедуру наукового пізнання в лінгвістиці, дозволяє чітко окреслити матеріальність та інтерпретованість дискурсивної системи.

Як наслідок, фрактальна теорія є особливим методологічним напрямом, який уможливлює програмування складної багаторівневої системи, якою є дискурс, із залученням самоподібних моделей та процедури метафоричного ототожнення рекурсивних смислових компонентів. У розвитку дискурсу закладений еволюційний принцип єдності та взаємозв'язку всього сущого в його саморусі від частини до цілого, від простого до складного, від статики до динаміки. Фрактальна метафора уналежнює дискурсивну реальність до інших природних процесів і форм реальності безвідносно до масштабів простору та часу. Вона дає методологічну можливість установити зв'язок між явищами різних системних рівнів дискурсу, включно 3 екстралінгвальними.

\section{Література}

[1] Дворецкий, И. Х. 2000. Латинско-русский словарь. Москва : Русс. яз.

[2] Дейк ван, Т. А. 1989. Язык. Познание. Коммуникация : сборник работ. Москва : Прогресс.

[3] Домброван, Т. И. 2014. Синергетическая модель развития английского языка: монография. Одесса : КП ОГТ.

[4] Єнікєєва, С. М. 2011. Система словотвору сучасної англійської мови: синергетичний аспект (на матеріалі новоутворень кінця XX - початку XXI століть). Автореф. дис. доктора філол. наук. Київ. нац. лінгв. ун-т.

[5] Жаботинская, С. А. 2018. Генеративизм, когнитивизм и семантика лингвальных сетей. Doctrina multiplex, veritas una. Учень багато, icmuна одна: збірник праць до ювілею Ізабелли Рафаїлівни Буніятової, 99-141. Київ: Київ, ун-т ім. Б. Грінченка.

[6] Жаботинская, С. А. 2013. Имя как текст: концептуальная сеть лексического значения (анализ имени эмоции). Когниция, коммуникация, дискурс, 6:47-76, https://doi.org/10.26565/2218-2926-2013-06-04.

[7] Кійко, Ю. Є. 2017. Фрактальне моделювання інваріантно-варіантної структури медіатекстів у німецькій та українській мовах. Дис. доктора філол. наук. Чернівці.

[8] Личутин, А. В. 2006. Онтология рекурсивных структур. Дис. канд. филол. наук. Архангельск. 
[9] Пихтовникова, Л. С. 2015. Самоорганизация дискурса и отдельных типов дискурса. Синергетика в филологических исследованиях: монография / под общ. ред. проф. Л. С. Пихтовниковой, 102-135. Харьков : ХНУ имени В.Н. Каразина.

[10] Плотникова, С. Н. 2011. Фрактальность дискурса как новое лингвистическое понятие. Вестник Иркутского государственного лингвистического университета, 3 (15):126-134.

[11] Симонов, К. И. 2013. Фракталь в языковой материи: монография. Москва: Тезаурус.

[12] Таценко, Н. В. 2018. Емпатія в сучасному англомовному дискурсі: когнітивно-синергетичний вимір. Дис. ... доктора філол. наук. Харків. нац. ун-т ім. В.Н. Каразіна

[13] Шевченко, И. С. Концептуализация коммуникативного поведения в дискурсе. Как нарисоватъ портрет птицы: методология когнитивно-коммуникативого анализа языка: кол. монографія / под ред. И. С. Шевченко, 106-147. Харьков: ХНУ имени В.Н. Каразина.

[14] Chomsky, N. 1993. Language and thought. Wakefield, Rhode Island \& London: Moyer Bell.

[15] Garcia, E. A. 1999. The use of complex adaptive systems in organizational studies. The evolution of complexity / F. Heylighen, J. Bollen, A. Riegler (eds.). Dordrecht, The Netherlands: Kluver Academic Publishers; Brussels, Belgium: VUB Univ. Press.

[16] Langacker, R. W. 2008. Cognitive grammar: a basic introduction. New York: Oxford University Press.

[17] Mandelbrot, B. B. 1982. The fractal geometry of nature. San Francisco: W. H. Freeman and Co.

[18] Martin, R. R. George. 2011. A game of thrones. Harper Voyager.

[19] Today. 2019. https://www.todayonline.com/world/paris-historic-notredame-cathedral-hit-fire.

\section{References}

[1] Dvoretskiy, I. H. 2000. Latinsko-russkiy slovar [Latin-Russian Dictionary]. Moskva: Russ. yaz.

[2] Dijk van, T. A. 1989. Yazyik. Poznanie. Kommunikatsiya: sbornik rabot [Language. Cognition. Communication: a Collection of Works]. Moskva: Progress.

[3] Dombrovan, T. I. 2014. Sinergeticheskaya model razvitiya angliyskogo yazyika: monografiya [Synergetic Model of the English Language Development: a Monograph]. Odessa : KP OGT.

[4] Ienikieieva, S. M. 2011. Systema slovotvoru suchasnoi anhliiskoi movy: synerhetychnyi aspekt (na materiali novoutvoren kintsia XX - pochatku XXI stolit) [Synergetic Approach to Word-formation System in Modern English: A Study of Late $20^{t h}$ - Early $21^{\text {st }}$ Centuries Language Innovations]: Philology Dr. Diss. Synops: Kyiv.

[5] Zhabotinskaya, S. A. 2018. Generativizm, kognitivizm i semantika lingvalnyih setey [Generativeism, Cognitivism, and Semantics of Lingual Networks]. Doctrina multiplex, veritas una. Uchen bahato, istyna odna: 
zbirnyk prats do yuvileiu Izabelly Rafailivny Buniiatovoi [Many Doctrines, One Truth: a Collection of Works for the Anniversary of Isabella Rafailivna Buniiatova], 99-141. Kyiv: Kyiv, un-t im. B. Hrinchenka

[6] Zhabotinskaya, S. A. 2013. Imya kak tekst: kontseptualnaya set leksicheskogo znacheniya (analiz imeni emotsii) [The Name as a Text: Conceptual Network of Lexical Meaning (Analysis of the Name of Emotion)]. Kognitsiya, kommunikatsiya, diskurs [Cognition, Communication, Discourse], 6:47-76, https://doi.org/10.26565/2218-2926-2013-06-04.

[7] Kiiko, Yu. Ye. 2017. Fraktalne modeliuvannia invariantno-variantnoi struktury mediatekstiv u nimetskii ta ukrainskii movakh [Fractal Modeling of Invariant-Variant Structure of Media Texts in German and Ukrainian Languages]: Philology Dr. Diss.: Chernivtsi.

[8] Lichutin, A. V. 2006. Ontologiya rekursivnyih struktur [Ontology of Recursive Structures]: Philology PhD. Diss.: Arhangelsk.

[9] Pihtovnikova, L. S. 2015. Samoorganizatsiya diskursa i otdelnyih tipov diskursa [Self-Organization of Discourse and Certain Types of Discourse]. Sinergetika $v$ filologicheskih issledovaniyah: monografiya [Synergetics in Philological Research: a Monograph], 102-135. Harkov: HNU imeni V. N. Karazina.

[10] Plotnikova, S. N. 2011. Fraktalnost diskursa kak novoe lingvisticheskoe ponyatie [Fractality of Discourse as a New Linguistic Concept]. Vestnik Irkutskogo gosudarstvennogo lingvisticheskogo universiteta, 3 (15): 126134.

[11] Simonov, K. I. 2013. Fraktalyi v yazyikovoy materii: monografiya [Fractals in Linguistic Matter: a Monograph]. Moskva: Tezaurus.

[12] Tatsenko, N. V. 2018. Empatiia v suchasnomu anhlomovnomu dyskursi: kohnityvno-synerhetychnyi vymir [Empathy in Modern English Discourse: Cognitive and Synergetic Dimensions]: Philology Dr. Diss. Kharkiv: HNU imeni V. N. Karazina.

[13] Shevchenko, I. S. Kontseptualizatsiya kommunikativnogo povedeniya v diskurse [The Conceptualization of Communicative Behavior in Discourse]. Kak narisovat portret ptitsyi: metodologiya kognitivno-kommunikativogo analiza yazyika: kol. monografiya [How to Draw a Portrait of a Bird: a Methodology for Cognitive and Communicative Analysis of a Language: a Collect. Monograph]. Harkov: HNU imeni V. N. Karazina.

[14] Chomsky, N. 1993. Language and thought. Wakefield, Rhode Island \& London: Moyer Bell.

[15] Garcia, E. A. 1999. The use of complex adaptive systems in organizational studies. The evolution of complexity / F. Heylighen, J. Bollen, A. Riegler (eds.). Dordrecht, The Netherlands: Kluver Academic Publishers; Brussels, Belgium: VUB Univ. Press.

[16] Langacker, R. W. 2008. Cognitive grammar: a basic introduction. New York: Oxford University Press.

[17] Mandelbrot, B. B. 1982. The fractal geometry of nature. San Francisco: W. H. Freeman and Co.

[18] Martin, R. R. George. 2011. A game of thrones. Harper Voyager.

[19] Today. 2019. https://www.todayonline.com/world/paris-historic-notredame-cathedral-hit-fire. 